\title{
Pewarisan Karakter Hortikultura Persilangan Syakira IPB x IPB C320 dalam Rangka Merakit Varietas Unggul Cabai Hias
}

\author{
Inheritance Study of Horticulture Charactersof Syakira IPB x IPB C320 \\ Crossing in Toward Breeding for Superior Varieties of Ornamental Peppers (Capsicum sp.)
}

\author{
Elsa Tirta Wulandari ${ }^{1}$, Muhamad Syukur ${ }^{1 *}$, Awang Maharijaya ${ }^{1}$ \\ ${ }^{1}$ Departemen Agronomi dan Hortikultura, Fakultas Pertanian, Institut Pertanian Bogor \\ (Bogor Agricultural University), Jalan Meranti, Kampus IPB Darmaga, Bogor 16680, Indonesia
}

Diterima 5 Desember 2017/Disetujui 19 Januari 2018

\begin{abstract}
Peppers have a high diversity of morphological traits including fruit color and shape. Crossings between genotypes that have different traits are one step in creating new, superior varieties. This study was aimed at analyzing gen action, the genetic diversity, correlation between characters, path analysis, broad-sense heritability, and the value of F2 genetic advance on the character of the number of fruit per plant. The study was conducted under a green house condition at Kebun Percobaan Leuwikopo IPB, Dramaga, Bogor and the laboratory of Genetics and Plant Breeding, Department of Agronomy and Horticulture, IPB. The study took place from October 2016 to March 2017. This study used the population of the F2 population Syakira IPB X IPB C320; 201 plants, P1 Syakira IPB; 21 plants, P2 IPB C320; 21 plants. The results showed that all characters qualitative controlled by two gens. The characters quantitative of flowering age, plant height, length of first segment, stem diameter, fruit diameter, fruit weight per plant, and number of fruit per plant have wide genetic diversity. All observed characters provide a positive correlation except the character of fruit weight and fruit diameter. Characters that directly affect the number of fruits per plant is weight of fruit per plant, fruit weight and plant height. The value of broadbased heritability with high criterion exists in all observed characters. Progress selection on the main character gives great value.
\end{abstract}

Key words: genetic variability, gen action, inheritance, ornamental peppers

\section{ABSTRAK}

Cabai memiliki keanekaragaman yang tinggi dan keragaan yang menarik. Persilangan antar genotipe yang memiliki keragaan yang berbeda merupakan salah satu langkah dalam menciptakan varietas baru yang unggul. Penelitian ini bertujuan untuk menganalisis aksi gen, keragaman genetik, korelasi antar karakter, sidik lintas, heritabilitas arti luas, dan nilai kemajuan seleksi populasi F2 pada karakter jumlah buah pertanaman. Penelitian dilaksanakan di Green House Kebun Percobaan Leuwikopo IPB, Dramaga, Bogor dan Laboratorium Genetika dan Pemuliaan Tanaman, Departemen Agronomi dan Hortikultura IPB. Penelitian berlangsung pada bulan Oktober 2016 sampai Maret 2017. Penelitian ini mengamati seluruh populasi yang terdiri dari 201 tanaman populasi F2 Syakira IPB XIPB C320, 21 tanaman P1 Syakira IPB, dan 21 tanaman P2 IPB C320. Hasil penelitian menunjukkan bahwa karakter kualitatifyang diamati dikendalikan oleh dua pasang gen. Karakter kuantitatif seperti umur berbunga, tinggi tanaman, panjang ruas pertama, diameter batang, diameter buah, bobot buah per tanaman, dan jumlah buah per tanaman memiliki keragaman genetik yang luas. Semua karakter yang diamati memberikan korelasi positif kecuali karakter bobot buah dan diameter buah. Karakter yang berpengaruh langsung terhadap jumlah buah per tanaman yaitu bobot buah per tanaman, bobot buah dan tinggi tanaman. Nilai heritabilitas arti luas dengan kriteria tinggi terdapat pada semua karakter yang diamati. Kemajuan seleksi pada karakter utama memberikan nilai yang besar.

Kata kunci: aksi gen, cabai hias, keragaman genetik, pewarisan

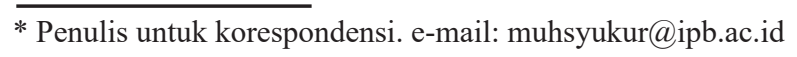




\section{PENDAHULUAN}

Cabai memiliki keanekaragaman yang tinggi dengan keragaan yang menarik sehingga dimanfaatkan untuk tanaman hias (Djarwaningsih, 2005). Tanaman cabai sebagai tanaman hias biasa ditanam dalam pot sehingga dapat dijadikan sebagai penghias ruangan maupun area pekarangan (Setiadi, 2002). Nilai estetika dari daun, bunga, dan buah menjadi daya tarik pada tanaman ini (Hessaallyon, 1993). Warna dan bentuk buah yang beragam mampu memberikan kesan yang indah (Bosland et al., 1994). Menurut Cayanti (2006) cabai hias yang diharapkan yaitu tanaman dengan tinggi tanaman yang proporsional, mempunyai banyak cabang sehingga tanaman terlihat lebih rimbun, mempunyai banyak buah sebagai daya tarik tanaman hias buah sehingga disukai konsumen dan menarik minat petani untuk lebih mengembangkan cabai hias.

Karakter kualitatif adalah karakter yang dapat dibedakan berdasarkan kelas atau jenis. Contoh karakter kualitatif adalah warna bunga, bentuk buah dan lain-lain. Bentuk sebaran kualitatif adalah tegas, gen pengendali karakter kualitatif berupa gen mayor, serta karakter kualitatif sangat sedikit dipengaruhi oleh lingkungan (Arif, 2010). Karakter kuantitatif adalah karakter yang dapat dibedakan berdasarkan dari segi nilai ukuran bukan jenisnya. Contohnya karakter-karakter yang berhubungan dengan pertumbuhan tanaman atau hasil panen. Karakter kuantitatif umumnya sangat dipengaruhi oleh lingkungan. Hal ini dapat terjadi karena karakter-karakter ini dikendalikan oleh sejumlah gen dimana pengaruh masing-masing gen terhadap penampilan karakter (fenotipe) lebih kecil dibandingkan pengaruh lingkungan, walaupun secara bersama-sama gengen tersebut dapat mempunyai pengaruh yang lebih besar dari pengaruh lingkungan. Gen-gen yang demikian disebut gen minor (Arif, 2010).

Pemuliaan cabai umumnya dilakukan melalui hibridisasi yang diikutidengan seleksi. Seleksi pada cabai akan memberikan kemajuan genetik yang tinggi jika karakter yang dilibatkan dalam seleksi mempunyai heritabilitas yang tinggi (Hilmayanti et al., 2006). Menurut Syukur et al. (2011) pewarisan atau heritabilitas perlu dilakukan untuk mengetahui pengaruh faktor genetik dan faktor lingkungan. Allard (1960) menyatakan bahwa nilai heritabilitas merupakan pernyataan kuantitatif peran genetik dalam memberikan keragaan akhir atau fenotipe suatu karakter. Keragaman genetik yang luas pada cabai merupakan modal dasar bagi kegiatan pemuliaan tanaman.

Besar kecilnya peranan faktor genetik terhadap fenotipe dinyatakan dengan heritabilitas atau daya waris. Pendugaan heritabilitas dapat dilakukan dengan dua cara yaitu melalui perhitungan ragam keturunan dan perhitungan analisis ragam (Crowder, 2006). Analisis pewarisan digunakan untuk mendapatkan informasi genetik yang terdiri atas jumlah gen, aksi gen, keragaman genetik, heritabilitas serta informasi-informasi genetik lainnya. Beberapa penelitian tentang pewarisan beberapa karakter pada cabai sudah dilakukan oleh Sreelathakumary dan Rajamony, 2004; Ganefianti et al., 2006; Lestari et al.,
2006; Arif et al., 2010; Yunianti et al., 2010; Syukur et al., 2011b; Qosim et al., 2013; Sujitno dan Dianawati, 2015. Analisis pewarisan dilakukan pada Syakira IPB dan IPB C320 untuk mengetahui besar pengaruh faktor genetik dan faktor lingkungan pada fenotipe yang muncul di generasi F2 yang dihasilkan sehingga akan memudahkan dalam merakit varietas baru cabai hias unggul.

\section{BAHAN DAN METODE}

Penelitian ini dilaksanakan di green house Kebun Percobaan Leuwikopo IPB, Dramaga, Bogor, dan Laboratorium Genetika dan Pemuliaan Tanaman, Departemen Agronomi dan Hortikultura IPB. Penelitian dilaksanakan pada bulan Oktober 2016 hingga Maret 2017. Bahan tanaman yang digunakan dalam penelitian ini adalah Syakira IPB (P1) dan IPB C320 (P2), populasi F2 hasil persilangan Syakira IPB x IPB C320. Penelitian ini menggunakan 243 tanaman yang terdiri atas Syakira IPB dan IPB C320 sebagai tetua P1 dan tetua P2 masing-masing sebanyak 21 tanaman serta populasi F2 hasil persilangan dari Syakira IPB x IPB C320 sebanyak 201 tanaman.

Pelaksanaan penelitian dimulai dengan penyemaian benih dengan menggunakan tray semai. Media tanam yang digunakan pada saat penyemaian adalah media tanam komersial. Media dimasukkan ke dalam lubang tray hingga penuh dan cukup padat. Setiap lubang dibuat lubang kecil dengan kedalaman $1 \mathrm{~cm}$. Benih dimasukkan sebanyak 1 benih per lubang, kemudian ditutup kembali. Pemeliharaan pada persemaian berupa penyiraman, pemupukan, dan pengendalian hama penyakit. Penyiraman dilakukan sehari sekali dengan menggunakan gembor. Pemupukan dilakukan jika tanaman yang telah mempunyai 2 daun dengan menggunakan $\mathrm{AB}$ Mix dengan dosis $5 \mathrm{ml} \mathrm{L}^{-1}$ yang diaplikasikan satu minggu sekali. Penanaman dilakukan dengan memindahkan bibit cabai berumur sekitar 5 minggu ke dalam pot yang telah berisi media tanam yang telah dipersiapkan satu minggu sebelumnya. Pengajiran dilakukan pada saat tanaman sudah berumur 1 MST dengan mengikatkan tali rafia pada ajir bambu.

Pemeliharaan tanaman meliputi penyiraman, penyiangan, pemupukan, pengendalian hama dan penyakit, dan penambahan media tanam. Penyiraman dilakukan setiap hari pada saat pagi. Penyiangan dilakukan secara manual dengan membuang gulma yang tumbuh di media pot. Pemupukan akan dilakukan setiap seminggu sekali dengan AB Mix dengan dosis $5 \mathrm{ml} \mathrm{L}^{-1}$. Pengendalian hama dilakukan satu minggu sekali dengan dengan menggunakan fungisida. Kegiatan pemanenan dilaksanakan pada buah yang sudah masak. Buah masak ditandai dengan $80 \%$ bagian buah berwarna merah hingga merah penuh. Kegiatan pemanenan dilakukan sebanyak 8 kali. Pemanenan dilakukan secara manual dengan interval setiap minggu.

Pengamatan dilakukan terhadap karakter kualitatif dan kuantitatif dengan mengacu pada Pedoman Descriptors for Capsicum (Capsicum spp.) oleh Naktuinbouw Calibration Book Capsicum annuum. L tahun 2010 dan IPGRI (International Plant Genetic Resources Institute) tahun 
1995. Pengamatan dilakukan pada seluruh populasi tanaman cabai yang ditanam. Karakter kualitatif terdiri dari bentuk buah, bentuk ujung buah, intensitas antosianin pada buah, dan perubahan warna. Karakter kuantitatif yang diamati meliputi umur berbunga (HST/Hari Setelah Tanam), umur panen (HST), tinggi tanaman $(\mathrm{cm})$, tinggi dikotomus $(\mathrm{cm})$, panjang ruas pertama $(\mathrm{cm})$, diameter batang $(\mathrm{mm})$, bobot per buah $(\mathrm{g})$, panjang per buah $(\mathrm{cm})$, diameter buah $(\mathrm{mm})$, bobot buah per tanaman $(\mathrm{g})$, dan jumlah buah pertanaman (buah).

Data kualitatif hasil pengamatan dianalisis dengan menggunakan uji khi-kuadrat dan dibandingkan dengan mendelian nisbah fenotipe karakter yang dikendalikan oleh gen mayor pada populasi bersegregasi F2 (Burns, 1976; Crowder, 2006). Data kuantitatif dianalisis untuk mengetahui nilai heritabilitas arti luas $\left(\mathrm{h}^{2}{ }_{\mathrm{bs}}\right)$ mengacu pada metode Mahmud-Kramer (Syukuret al., 2012) yaitu :

$$
\mathrm{h}^{2} \mathrm{bs}=\frac{\sigma^{2} \mathrm{~F} 2-\sqrt{\sigma^{2} P 1 \times \sigma^{2} P 2}}{\sigma^{2} \mathrm{~F} 2} \times 100 \%
$$

Keterangan: $h^{2}$ bs $=$ heritabilitas dalam arti luas, $\sigma^{2} \mathrm{~F} 2=$ ragam fenotipe dari populasi $\mathrm{F} 2, \sigma^{2} \mathrm{P} 1=$ ragam populasi $\mathrm{P} 1$, $\sigma^{2} \mathrm{P} 2=$ ragam populasi $\mathrm{P} 2$

Karakter seleksi utama yang digunakan dalam penelitian ini yaitu jumlah buah per tanaman. Seleksi terhadap karakter utama ini menggunakan taraf $10 \%$ tanaman terbaik dari seluruh tanaman F2. Genotipe yang terseleksi dihitung kemajuan seleksi dengan menggunakan rumus (Falconer, 1981; Syukur et al.,2015):

$$
\begin{gathered}
\Delta G=S h^{2} b s \quad \% \Delta G=\frac{\Delta G}{\bar{x}_{p}} \times 100 \% \quad \mathrm{~S}=\left|\bar{x}_{t}-\bar{x}_{p}\right| \\
\text { Peubah } \\
\text { adalah kemajuan seleksi, adalah }
\end{gathered}
$$
heritabilitas, $\mathrm{S}$ adalah diferensial seleksi, adalah nilai tengah populas $\hat{A} \boldsymbol{G}$ rseleksi, dan adalah nilai $\boldsymbol{h}^{2} \boldsymbol{b} \boldsymbol{s} \boldsymbol{s}$ ah awal populasi. Analisis data dilakukan menggunăk $\bar{x}_{\bar{k}}$ an perangkat lunak SAS 9.0 dan Microsoft Ex $\bar{x}_{\mathfrak{e}} 2010$.

\section{HASIL DAN PEMBAHASAN}

\section{Karakter Kualitatif Populasi F2 Cabai Hias}

\section{Bentuk Buah}

Populasi Syakira IPB memiliki bentuk buah yang segitiga menyempit (narrowly triangular) dan populasi IPB C320 memiliki bentuk buah segitiga luas (moderately triangular). Persentase populasi F2 bentuk buah segitiga menyempit (narrowly triangular) dan bentuk buah segitiga luas (moderately triangular) adalah sebesar 62.5\% dan $37.5 \%$. Nilai $\mathrm{X}_{\text {hitung }}$ pada populasi F2 Syakira IPB dan IPB C320 sebesar 2.54 lebih kecil dari $\mathrm{X}_{\text {tabel }}^{2}$ sebesar $3.84(\mathrm{db}=$ $1 ; \alpha=5 \%$ ) (Tabel 1).

Nilai $\mathrm{X}_{\text {hitung }}^{2}$ yang lebih besar dariX ${ }_{\text {tabel }}^{2}$ menunjukkan bahwa perbandingan pengamatan karakter kualitatif bentuk buah sesuai dengan perbandingan harapan 9:7 yang merupakan tipe aksi gen epistasis resesif ganda yang dikendalikan oleh dua gen (Gambar 1). Hal ini terjadi karena adanya salah satu gen yang bersifat homozigot resesif sehingga menutupi sifat gen yang lain (Sobir dan Syukur, 2015).

\section{Bentuk Ujung Buah}

Cabai hias populasi P1 memiliki bentuk ujung buah yang runcing sedangkan populasi P2 memiliki bentuk ujung buah yang tumpul. Persentase bentuk ujung buah pada populasi F2 Syakira IPB dan IPB C320 sebesar $93.75 \%$ dan $6.25 \%$ (Tabel 2).

Nilai $X_{\text {hitung }}^{2}$ pada populasi F2 Syakira IPB dan IPB C320 pada karakter bentuk ujung buah sebesar 00.00 lebih kecil dari $\mathrm{X}^{2}$ tabel sebesar $3.84(\mathrm{db}=1 ; \alpha=5 \%)$. Gambar 2 menjabarkan persentase perbandingan $15: 1$ yang termasuk dalam epistasis dominan ganda. Epistasis dominan ganda dikendalikan oleh dua gen. Hal ini terjadi karena adanya

Tabel 1. Nilai $\mathrm{X}_{\text {hitung }}$ bentuk buah cabai hias pada populasi F2 Syakira IPB x IPB C320 dengan perbandingan $9: 7$

\begin{tabular}{lccc}
\hline \multicolumn{1}{c}{ Populasi } & Moderatly & Narrowly & $\mathrm{X}_{\text {hitung }}^{2}$ \\
\hline Syakira IPB & - & $21 \operatorname{tanaman}(100 \%)$ & \\
IPB C320 & $21 \operatorname{tanaman}(100 \%)$ & - & \\
F2 Syakira IPB X IPB C320 & $100 \operatorname{tanaman}(62.5 \%)$ & $60 \operatorname{tanaman}(37.5 \%)$ & 2.54 \\
\hline
\end{tabular}

Tabel 2.Nilai $\mathrm{X}_{\text {hitung }}^{2}$ bentuk ujung buah cabai hias pada populasi F2 Syakira IPB x IPB C320 dengan perbandingan $15: 1$

\begin{tabular}{lccc}
\hline \multicolumn{1}{c}{ Populasi } & Runcing & Tumpul & $\mathrm{X}_{\text {hitung }}^{2}$ \\
\hline Syakira IPB & $21 \operatorname{tanaman}(100 \%)$ & - & \\
IPB C320 & - & $21 \operatorname{tanaman}(100 \%)$ & 0 \\
F2 Syakira IPB X IPB C320 & $150 \operatorname{tanaman}(93.75 \%)$ & $10 \operatorname{tanaman}(6.25 \%)$ & 0 \\
\hline
\end{tabular}


salah satu gen yang bersifat dominan sehingga menutupi sifat gen yang lain (Sobir dan Syukur, 2015).

\section{Antosianin Buah}

Populasi tetua baik Syakira IPB maupun IPB C320 memiliki kandungan antosianin yang terlihat dari semburat ungu yang terdapat pada buah muda. Populasi F2 Syakira IPB dan IPB C320 memiliki intensitas antosianin sebesar $77.5 \%$ dan $22.5 \%$ (Tabel 3). Persentase ini apabila dijadikan bentuk perbandingan sebesar $13: 3$ termasuk pada tipe aksi gen epistasis dominan dan resesif (Gambar 3). Aksi gen resesif dikendalikan oleh dua pasang gen. Hal ini terjadi karena adanya dua gen yang dominan, maka gen yang lain tertekan atau tertutupi oleh sifat fenotipe gen lainnya (Sobir dan Syukur, 2015).

Keragaman Genetik Karakter Kuantitatif Populasi F2 Syakira IPB x IPB C320

Tabel 4 menyajikan nilai rataan dan rentang karakter kuantitatif yang di amati pada populasi P1, P2, P3. Populasi P1 memiliki rataan umur berbunga sebesar 17.76 HST, populasi P2 memiliki rataan umur berbunga sebesar 18.57 HST dan populasi F2 memiliki rataan umur berbunga sebesar 23.42 HST. Populasi F2 memiliki rataan umur berbunga lebih lama dari tetuanya dan rentang umur berbunga yang juga lebih besar, tetapi apabila dilihat per individu populasi F2 memiliki umur berbunga lebih awal dari tetuanya. Umur panen pada populasi P1 dimulai pada umur $54 \mathrm{HST}$, populasi P2 cenderung jauh lebih lama dari populasi P1 pada umur 70 HST dan populasi F2 mulai memasuki panen pada umur yang sama seperti populasi P1 pada 54 HST tetapi memiliki rentang yang lebih besar dibanding kedua tetuanya. Rataan tinggi tanaman, tinggi dikotomus dan panjang ruas pertama populasi P1 dan F2 hampir sama. Rataan tinggi tanaman, tinggi dikotomus, dan panjang ruas pertama pada populasi P2 lebih rendah dari populasi P1 dan F2. Rataan nilai karakter lain seperti diameter batang dan diameter buah pada populasi P2 paling besar, kemudian kedua terbesar pada rataan populasi $\mathrm{F} 2$ dan yang terakhir rataan populasi P1. Pada karakter bobot per buah dan bobot buah per tanaman nilai rataan berurutan dari tertinggi hingga terendah pada populasi F2, kemudian populasi P2 dan populasi P1. Rataan panjang buah terbesar dimiliki oleh populasi P1, kemudian F2 dan P2. Jumlah buah pertanaman nilai rataan tertinggi hingga terendah yaitu populasi P1, P2, F2.

Rentang nilai yang dimiliki oleh populasi F2 lebih luas dan lebih besar dibanding populasi P1 dan P2. Rentang ini menyebabkan rataan populasi F2 yang diterima oleh populasi F2 menjadi lebih kecil terlihat pada karakter jumlah buah per tanaman. Diameter batang, panjang buah, diameter buah yang dimiliki populasi F2 berada di tengah kedua tetuanya. Karakter bobot per buah dan bobot buah per tanaman populasi F2 paling tinggi dibanding kedua tetuanya. Keragaman genetik yang besar memiliki peluang yang lebih tinggi untuk mendapatkan sumber genetik dari karakter yang diinginkan. KKG pada karakter-karakter

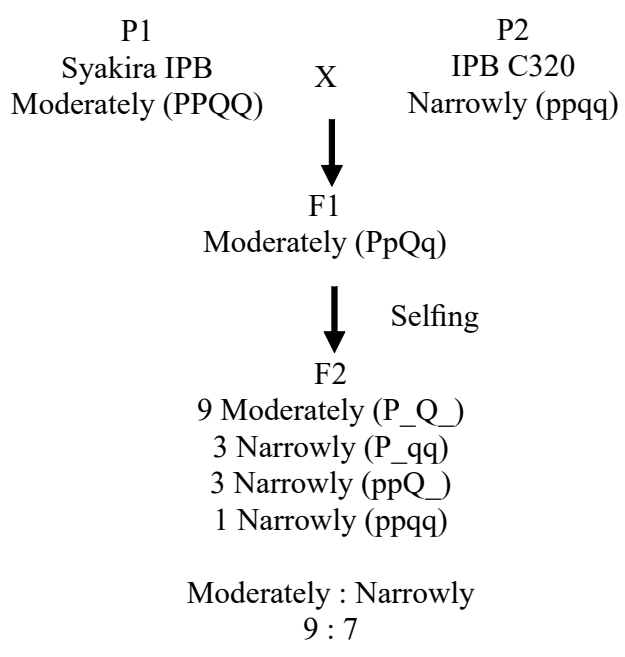

Gambar 1. Bagan persilangan dan model genotipe untuk gen yang mengendalikan karakter bentuk buah hasil persilangan syakira IPB x IPB C320

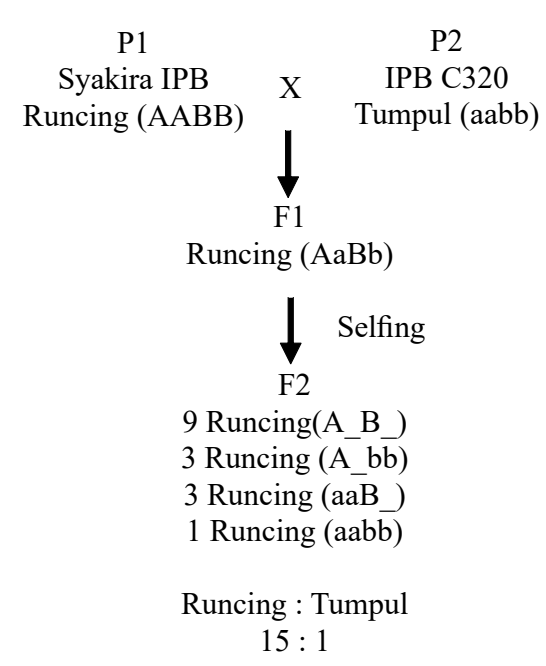

Gambar 2. Bagan persilangan dan model genotipe untuk gen yang mengendalikan karakter bentuk ujung buah hasil persilangan Syakira IPB x IPB C320

P1

$\begin{array}{ccc}\text { Syakira IPB } & \text { X } & \text { IPB C320 } \\ \text { Ada (DDKK) } & \bigsqcup^{\downarrow} & \text { Ada (ddkk) } \\ \text { Ada (DdKk) } & \end{array}$

$$
\begin{gathered}
\bigsqcup \text { Selfing } \\
\text { F2 } \\
\text { 9da (D_K_ }) \\
\text { 3 Ada (D_kk) } \\
\text { 3 Tidak Ada (ddK_) } \\
1 \text { Ada (ddkk) } \\
\text { Ada : Tidak Ada } \\
13: 3
\end{gathered}
$$

Gambar 3. Bagan persilangan dan model genotipe untuk gen yang mengendalikan karakter antosianin buah hasil persilangan Syakira IPB x IPB C320 
yang diamati berada pada rentang $10.50-36.48$ (Tabel 4). Nilai KKG tertinggi terdapat pada karakter bobot buah per tanaman dengan nilai 36.48. Karakter dengan nilai KKG terendah pada umur panen dengan nilai 10.50 .

Hasil dari Tabel 5 ini sejalan dengan penelitian sebelumnya yang menunjukkan bahwa terdapat keragaman genetik yang luas untuk karakter bobot buah (Sreelathakumary dan Rajamony, 2004; Yunianti et al., 2010; Syukur et al., 2011b), bobot buah per tanaman (Sreelathakumary dan Rajamony, 2004; jumlah buah per tanaman (Lestari et al., 2006; Syukur et al., 2011b); Syukur et al., 2011b).

Heritabilitas Arti Luas Karakter Kuantitatif F2 Syakira IPB $x$ IPB C320

Nilai duga heritabilitas pada karakter-karakter yang diamati berada pada rentang 59\% hingga 87\% (Tabel 6). Pendugaan heritabilitas diperlukan untuk memprediksi besar faktor lingkungan atau faktor genetik yang mempengaruhi suatu fenotipe. Nilai heritabilitas yang tinggi menunjukkan bahwa karakter yang terekspresikan dalam suatu fenotipe lebih banyak dipengaruhi oleh faktor genetik dibanding faktor lingkungan. Nilai heritabilitas yang tinggi akan berperan penting dalam keefektifan kegiatan seleksi (Syukur et al., 2011). Semua karakter yang diamati memiliki nilai heritabilitas yang tinggi. Nilai heritabilitas tertinggi terdapat pada karakter umur berbunga (89\%) dan karakter dengan nilai heritabilitas terendah pada tinggi tanaman (59\%). Hasil ini sejalan dengan penelitian sebelumnya yang menunjukkan bahwa karakter bobot buah per tanaman memiliki nilai heritabilitas arti luas pada kriteria tinggi (Streelathakumary dan Rajamony, 2004; Lestari et al., 2006; Marame et al., 2008; Syukur et al., 2011a; Syukur et al., 2011b; Qosim et al., 2013; dan Undang, 2014). Karakter panjang buah dengan heritabilitas arti luas kriteria tinggi, sejalan dengan penelitian sebelumnya yang pernah dilakukan oleh Marame et al., (2008) dan Syukur et al., (2011b). Karakter jumlah buah per tanaman dengan heritabilitas arti luas kriteria tinggi, sejalan dengan penelitian yang dilakukan Qosim et al., (2013) dan Undang (2014) sedangkan Syukur et al., (2011a) menunjukkan bahwa jumlah buah per tanaman memiliki heritabilitas arti luas pada kriteria sedang.

\section{Korelasi Antar Karakter Kuantitatif Populasi F2 Syakira IPB $x$ IPB C320}

Tabel 7 menyajikan koefisien korelasi antar karakter yang diamati pada populasi cabai hias F2 Syakira IPB x IPB C320. Hasil analisis korelasi menunjukkan bahwa umur berbunga berkorelasi positif dan sangat nyata terhadap umur panen, sejalan dengan penelitian yang telah dilakukan

Tabel 3. Nilai $\mathrm{X}^{2}{ }_{\text {hitung }}$ Intensitas antosianin buah cabai hias pada populasi F2 Syakira IPB x IPB C320 dengan perbandingan $13: 3$

\begin{tabular}{lccc}
\hline \multicolumn{1}{c}{ Populasi } & Ada & Tidak Ada & $\mathrm{X}_{\text {hitung }}^{2}$ \\
\hline Syakira IPB & $21 \operatorname{tanaman}(100 \%)$ & - & \\
IPB C320 & $21 \operatorname{tanaman}(100 \%)$ & - & 1.48 \\
F2 Syakira IPB X IPB C320 & $124 \operatorname{tanaman}(77.5 \%)$ & $36 \operatorname{tanaman}(22.5 \%)$ & \\
\hline
\end{tabular}

Tabel 4. Rekapitulasi rataan dan rentang data karakter yang diamati pada populasi Syakira IPB, IPB C320 dan F2 Syakira IPB x IPB C320

\begin{tabular}{lcccccc}
\hline & \multicolumn{2}{c}{ Syakira IPB } & \multicolumn{2}{c}{ IPB C320 } & \multicolumn{2}{c}{ Syakira IPB X IPB C320 } \\
\hline \multicolumn{1}{c}{ Karakter } & Rataan & Rentang & Rataan & Rentang & Rataan & Rentang \\
Umur Berbunga (HST) & 17.76 & $13-22$ & 18.57 & $14-23$ & 23.42 & $12-39$ \\
Umur Panen (HST) & 57.33 & $54-61$ & 73.67 & $70-91$ & 63.48 & $54-94$ \\
Tinggi Tanaman (cm) & 37.03 & $28.30-46.50$ & 32.18 & $22.00-47.00$ & 37.07 & $16.10-80.70$ \\
Tinggi Dikotomus (cm) & 15.13 & $14.00-16.00$ & 11.72 & $9.00-15.00$ & 14.15 & $6.00-27.00$ \\
Panjang Ruas Pertama (cm) & 3.19 & $2.45-3.85$ & 2.46 & $1.85-3.50$ & 3.23 & $1.40-9.75$ \\
Diameter Batang (mm) & 8.32 & $6.53-10.10$ & 10.17 & $6.06-14.89$ & 9.46 & $1.77-16.89$ \\
Bobot per Buah (g) & 1.32 & $0.76-2.09$ & 1.43 & $0.96-1.67$ & 1.71 & $0.75-3.48$ \\
Panjang Buah (cm) & 4.55 & $3.08-5.66$ & 2.66 & $2.2-3.2$ & 3.95 & $2.54-5.54$ \\
Diameter Buah (mm) & 7.10 & $5.91-8.50$ & 10.76 & $8.23-12.83$ & 9.30 & $5.46-14.06$ \\
Bobot per Tanaman (g) & 126.39 & $91.54-227.18$ & 138.65 & $48.37-189.64$ & 190.03 & $54.47-555.88$ \\
Jumlah Buah per Tanaman (buah) & 128.31 & $88-177$ & 115.67 & $44-173$ & 115.34 & $35-336$ \\
\hline
\end{tabular}


oleh Sidiq (2016). Karakter yang berkorelasi positif dan sangat nyata terhadap jumlah buah per tanaman yaitu tinggi tanaman, tinggi dikotomus, panjang ruas pertama, diameter batang dan bobot buah per tanaman. Karakter lain seperti umur berbunga, umur panen dan panjang buah turut berkorelasi positif terhadap jumlah buah per tanaman meskipun tidak nyata. Korelasi negatif terhadap jumlah buah per tanaman terdapat pada karakter bobot buah dan diameter buah.

Analisis korelasi hanya menjabarkan keeratan hubungan antar karakter yang diamati tanpa memperhatikan besar pengaruh lain terhadap karakter tersebut. Analisis sidik lintas (path analysis) dapat menunjukkan besar pengaruh suatu nilai terhadap karakter utama baik langsung ataupun tidak langsung yang biasanya dihubungkan dengan hasil (Deviona et al., 2011).

Berdasarkan hasil sidik lintas pada Tabel 8, karakter yang memiliki pengaruh langsung terhadap jumlah buah per tanaman adalah bobot buah per tanaman, bobot buah serta tinggi tanaman. Bobot buah per tanaman memiliki nilai korelasi genetik langsung tertinggi sebesar 0.88 . Bobot buah memiliki nilai korelasi genetik langsung sebesar 0.21 ke arah kiri. Karakter tinggi tanaman memiki nilai korelasi genetik langsung sebesar 0.11 .

\section{Seleksi dan Kemajuan Seleksi Karakter Kuantitatif Genotipe F3 Cabai Rawit}

Seleksi merupakan dasar untuk merakit dan meningkatkan varietas baru. Kegiatan seleksi akan efektif apabila menggunakan karakter dengan heritabilitas tinggi (Mustafa et al., 2016). Hal ini disebabkan adanya faktor genetik yang lebih besar dari faktor lingkungan yang berperan dalam penentuan fenotipe suatu karakter (Carsono

Tabel 5. Koefisien keragaan genetik setiap karakter pada populasi F2 Syakira IPB X IPB C320

\begin{tabular}{|c|c|c|c|c|c|}
\hline Karakter & $\sigma^{2} \mathrm{G}$ & Stdev & $\mathrm{X}$ & $\mathrm{KKG}$ & Kriteria \\
\hline Umur Berbunga (HST) & 26.42 & 5.14 & 23.42 & 21.94 & luas \\
\hline Umur Panen (HST) & 44.44 & 6.67 & 63.48 & 10.5 & sedang \\
\hline Tinggi Tanaman $(\mathrm{cm})$ & 75.83 & 8.71 & 37.07 & 23.49 & luas \\
\hline Tinggi Dikotomus (cm) & 7.76 & 2.79 & 14.15 & 19.69 & sedang \\
\hline Panjang Ruas Pertama (cm) & 0.73 & 0.86 & 3.23 & 26.54 & luas \\
\hline Diameter Batang (mm) & 4.31 & 2.08 & 9.46 & 21.96 & luas \\
\hline Bobot per Buah (g) & 0.14 & 0.37 & 1.71 & 21.86 & luas \\
\hline Panjang Buah (cm) & 0.28 & 0.53 & 3.95 & 1342 & sedang \\
\hline Diameter Buah (mm) & 1.52 & 1.23 & 9.3 & 13.26 & sedang \\
\hline Bobot per Tanaman $(\mathrm{g})$ & 4806.51 & 69.33 & 190.03 & 36.48 & luas \\
\hline Jumlah Buah per Tanaman (buah) & 1416.19 & 37.63 & 115.34 & 32.63 & luas \\
\hline
\end{tabular}

Keterangan : $\sigma 2 \mathrm{G}=$ ragam genetik, $\mathrm{Stdev}=$ standar deviasi, $\mathrm{X}=$ rataan genotipe, $\mathrm{KKG}=$ koefisien keragaman genetik, HST $=$ hari setelah tanam

Tabel 6. Nilai duga komponen ragam dan heritabilitas arti luas tiap karakter populasi F2 Syakira IPB X IPB C320

\begin{tabular}{|c|c|c|c|c|c|}
\hline Karakter & $\sigma^{2} \mathrm{E}$ & $\sigma^{2} \mathrm{G}$ & $\sigma^{2} \mathrm{P}$ & $\mathrm{h}^{2} \mathrm{bs}(\%)$ & Kriteria \\
\hline Umur Berbunga (HST) & 4.12 & 26.42 & 30.46 & 87 & tinggi \\
\hline Umur Panen (HST) & 25.08 & 44.44 & 66.33 & 67 & tinggi \\
\hline Tinggi Tanaman $(\mathrm{cm})$ & 53.19 & 75.83 & 127.78 & 59 & tinggi \\
\hline Tinggi Dikotomus (cm) & 1.89 & 7.76 & 9.02 & 86 & tinggi \\
\hline Panjang Ruas Pertama (cm) & 0.22 & 0.73 & 0.95 & 77 & tinggi \\
\hline Diameter Batang (mm) & 3.88 & 4.31 & 7.12 & 61 & tinggi \\
\hline Bobot per Buah (g) & 0.07 & 0.14 & 0.21 & 68 & tinggi \\
\hline Panjang Buah (cm) & 0.22 & 0.28 & 0.44 & 64 & tinggi \\
\hline Diameter Buah (mm) & 0.92 & 1.52 & 2.30 & 66 & tinggi \\
\hline Bobot per Tanaman (g) & 1783.43 & 4806.51 & 6571.84 & 73 & tinggi \\
\hline Jumlah Buah per Tanaman (buah) & 754.99 & 1416.19 & 2168.64 & 65 & tinggi \\
\hline
\end{tabular}

Keterangan : $\sigma 2 \mathrm{E}$ = ragam lingkungan, $\sigma 2 \mathrm{G}=$ ragam genetik, $\sigma 2 \mathrm{P}=$ ragam fenotipe, h2bs= nilai heritabilitas arti luas 
et al., 2004). Fehr (1987) menyatakan apabila nilai duga heritabilitas tinggi maka seleksi dapat dilakukan pada generasi awal yaitu F2 dan F3 karena karakter dari genotipe tersebut mudah diwariskan. Informasi lain yang dibutuhkan dalam kegiatan seleksi antara lain korelasi dan sidik lintas antar berbagai karakter terhadap karakter utama yang diinginkan (Ganefianti et al., 2006).

Karakter pada populasi cabai hias F2 Syakira IPB x IPB C320 yang dijadikan sebagai karakter utama seleksi adalah karakter jumlah buah per tanaman. Karakter jumlah buah per tanaman digunakan sebagai karakter utama karena pada penelitian cabai sebelumnya oleh Sidiq (2016) menunjukkan kemajuan seleksi yang besar. Hasil seleksi pada karakter ini menghasilkan 10 tanaman dengan jumlah buah buah tertinggi dan memiliki karakter kalitatif yang menarik. Nomor tanaman yang terseleksi antara lain 73, 151, $66,176,125,164,150,105,96$ dan 144 (Tabel 9). Adanya 10 tanaman terpilih dengan jumlah buah per tanaman terbanyak ini masih perlu dilakukan analisis kemajuan seleksi untuk mempertegas bahwa terdapat perbaikan hasil dari populasi awal. Hasil analisis yang disajikan pada Tabel 9 menunjukkan bahwa nilai rataan populasi terseleksi lebih besar dari nilai rataan populasi awal. Hal ini menandakan bahwa populasi yang diseleksi memiliki kemajuan seleksi yang lebih baik dari populasi sebelumnya.

Tabel 7. Koefisien korelasi antar karakter pada populasi F2 Syakira IPB X IPB C320

\begin{tabular}{|c|c|c|c|c|c|c|c|c|c|c|}
\hline Karakter & UP & TT & $\mathrm{TD}$ & PRP & DT & $\mathrm{BB}$ & PB & DB & BBT & JBT \\
\hline UB & $0.66^{* *}$ & $0.27 * *$ & 0.03 & $0.21 * *$ & 0.13 & 0.10 & 0.05 & -0.02 & 0.02 & 0.00 \\
\hline UP & & $0.23 * *$ & 0.05 & 0.04 & 0.14 & 0.07 & -0.08 & 0.06 & 0.03 & 0.01 \\
\hline $\mathrm{TT}$ & & & $0.26^{* *}$ & $0.31 * *$ & $0.50 * *$ & 0.05 & 0.08 & -0.10 & $0.43 * *$ & $0.48^{* *}$ \\
\hline $\mathrm{TD}$ & & & & $0.33 * *$ & $0.25 * *$ & 0.00 & -0.11 & 0.07 & $0.26 * *$ & $0.28 * *$ \\
\hline PRP & & & & & $0.32 * *$ & 0.01 & 0.01 & -0.06 & $0.27 * *$ & $0.26^{* *}$ \\
\hline DT & & & & & & 0.11 & 0.07 & 0.08 & $0.49 * *$ & $0.46^{* *}$ \\
\hline $\mathrm{BB}$ & & & & & & & $0.39 * *$ & $0.74 * *$ & $0.16^{*}$ & -0.10 \\
\hline PB & & & & & & & & -0.13 & $0.21 * *$ & 0.13 \\
\hline DB & & & & & & & & & 0.08 & -0.14 \\
\hline BBT & & & & & & & & & & $0.90 * *$ \\
\hline
\end{tabular}

Keterangan : $\quad \mathrm{UB}=$ umur berbunga; $\mathrm{UP}=$ umur panen; $\mathrm{TT}=$ tinggi tanaman; $\mathrm{TD}=$ tinggi dikotomus; $\mathrm{PRP}=$ panjang ruas pertama; $\mathrm{DT}=$ diameter batang; $\mathrm{BB}=$ bobot buah; $\mathrm{PB}=$ panjang buah; $\mathrm{DB}=$ diameter buah; $\mathrm{BBT}=$ bobot buah per tanaman; $\mathrm{JBT}=$ jumlah buah per tanaman; $\mathrm{tn},{ }^{*}, * *=$ berturut-turut hasil uji $\mathrm{F}$ tidak nyata pada taraf $5 \%$, nyata pada taraf $5 \%$, dan nyata pada taraf $1 \%$

Tabel 8. Pengaruh langsung dan tidak langsung karakter yang diamati terhadap jumlah buah per tanaman

\begin{tabular}{|c|c|c|c|c|c|c|c|c|c|c|c|c|c|}
\hline \multirow{2}{*}{ Karakter } & \multirow{2}{*}{ Pengaruh langsung } & \multicolumn{10}{|c|}{ Pengaruh tidak langsung } & \multirow{2}{*}{ Total } & \multirow{2}{*}{ Selisih } \\
\hline & & UB & UP & TT & TD & PRP & DT & $\mathrm{BB}$ & PB & DB & BBT & & \\
\hline UB & -0.02 & & -0.01 & 0.03 & 0.00 & 0.00 & 0.00 & -0.02 & 0.00 & 0.00 & 0.02 & 0.00 & 0.02 \\
\hline UP & -0.02 & -0.01 & & 0.03 & 0.00 & 0.00 & 0.00 & -0.02 & 0.00 & 0.00 & 0.03 & 0.01 & 0.03 \\
\hline TT & 0.11 & 0.00 & 0.00 & & 0.01 & -0.01 & -0.01 & -0.01 & 0.00 & 0.00 & 0.38 & 0.48 & 0.37 \\
\hline TD & 0.03 & 0.00 & 0.00 & 0.03 & & -0.01 & 0.00 & 0.00 & 0.00 & 0.00 & 0.23 & 0.28 & 0.25 \\
\hline PRP & -0.02 & 0.00 & 0.00 & 0.03 & 0.01 & & 0.00 & 0.00 & 0.00 & 0.01 & 0.24 & 0.26 & 0.28 \\
\hline DT & 0.01 & 0.00 & 0.00 & 0.06 & 0.01 & -0.01 & & -0.02 & 0.00 & 0.00 & 0.43 & 0.46 & 0.45 \\
\hline BB & -0.21 & 0.00 & 0.00 & 0.01 & 0.00 & 0.00 & 0.00 & & 0.00 & -0.03 & 0.14 & -0.09 & 0.12 \\
\hline PB & 0.01 & 0.00 & 0.00 & 0.01 & 0.00 & 0.00 & 0.00 & -0.08 & & 0.01 & 0.18 & 0.13 & 0.11 \\
\hline DB & -0.04 & 0.00 & 0.00 & -0.01 & 0.00 & 0.00 & 0.00 & -0.16 & 0.00 & & 0.07 & -0.14 & -0.10 \\
\hline BBT & 0.88 & 0.00 & 0,00 & 0.05 & 0.01 & -0.01 & 0.01 & -0.03 & 0.00 & 0.00 & & 0.90 & 0.02 \\
\hline Sisa & 0.35 & & & & & & & & & & & & \\
\hline
\end{tabular}

Keterangan : $\quad$ UB = umur berbunga; UP = umur panen; TT = tinggi tanaman; TD = tinggi dikotomus; PRP = panjang ruas pertama; $\mathrm{DT}=$ diameter batang; $\mathrm{BB}=$ bobot buah; $\mathrm{PB}=$ panjang buah; $\mathrm{DB}=$ diameter buah; $\mathrm{BBT}=$ bobot buah per tanaman. 
Wulandari et al. / Comm. Horticulturae Journal 2(1):57-65

Tabel 9. Dugaan kemajuan seleksi pada populasi F2 terseleksi pada karakter jumlah buah per tanaman

\begin{tabular}{lcc}
\hline \multicolumn{1}{c}{ Genotipe } & Nomor tanaman & Jumlah buah per tanaman \\
\hline F2 Syakira IPB x IPB C320 & 73 & 336 \\
F2 Syakira IPB x IPB C320 & 151 & 268 \\
F2 Syakira IPB x IPB C320 & 66 & 238 \\
F2 Syakira IPB x IPB C320 & 176 & 211 \\
F2 Syakira IPB x IPB C320 & 125 & 200 \\
F2 Syakira IPB x IPB C320 & 164 & 191 \\
F2 Syakira IPB x IPB C320 & 150 & 188 \\
F2 Syakira IPB x IPB C320 & 105 & 185 \\
F2 Syakira IPB x IPB C320 & 96 & 185 \\
F2 Syakira IPB x IPB C320 & 144 & \\
$\overline{\boldsymbol{x}}_{\boldsymbol{p}}$ & 115.34 & \\
$\overline{\boldsymbol{x}}_{\boldsymbol{t}}$ & 222.20 & \\
$\mathrm{~S}$ & 115.34 & \\
$\mathrm{~h}^{2}$ bs (\%) & 65.00 & \\
$\Delta \mathrm{G}$ & 69.46 & \\
\hline
\end{tabular}

Keterangan : $\quad \overline{\boldsymbol{x}}_{\boldsymbol{p}}=$ nilai tengah populasi awal, $\overline{\boldsymbol{x}}_{\boldsymbol{t}}=$ nilai tengah populasi terseleksi, $\mathrm{S}=$ diferensial seleksi, $\mathrm{h}^{2} \mathrm{bs}(\%)=$ heritabilitas arti luas, $\Delta \mathrm{G}=$ kemajuan seleksi

\section{KESIMPULAN}

Hasil analisis menunjukkan bahwa karakter kualitatif pada karakter yang diamati dikendalikan oleh dua pasang gen. Karakter kuantitatif populasi F2 memiliki rentang data yang lebih besar dibandingkan pada populasi kedua tetuanya. Karakter umur berbunga, tinggi tanaman, panjang ruas pertama, diameter batang, bobot per buah, bobot buah per tanaman, dan jumlah buah per tanaman memiliki keragaman genetik yang luas. Karakter umur panen, tinggi dikotomus, panjang buah, dan diameter buah memiliki keragaman genetik sedang.

Seluruh karakter yang diamati memberikan korelasi positif kecuali karakter bobot buah dan diameter buah. Karakter yang berpengaruh langsung terhadap jumlah buah per tanaman yaitu bobot buah per tanaman, bobot buah, dan tinggi tanaman yang turut dipengaruhi oleh karakterkarakter tak langsung lainnya. Nilai heritabilitas arti luas dengan kriteria tinggi terdapat pada semua karakter yang diamati. Pengujian nilai kemajuan seleksi dilakukan pada karakter utama yaitu jumlah buah pertanaman. Individu yang terseleksi memiliki nilai rataan yang lebih baik dari rataan awal sehingga kemajuan seleksi yang diberikan besar.

\section{UCAPAN TERIMA KASIH}

Terima kasih disampaikan kepada Kemenristekdikti yang telah membiayai penelitian ini melalui hibah Penelitian Unggulan Perguruan Tinggi (PUPT) tahun 2017 a.n. Muhamad Syukur.

\section{DAFTAR PUSTAKA}

Allard, R.W. 1960. Priciples Of Plant Breeding. New York (USA).

Arif, A.B. 2010. Pendugaan parameter genetika beberapa karakter kualitatif dankuantitatif pada tiga kelompok cabai (Capsicum annuum L.). Tesis. Sekolah Pascasarjana, Institut Pertanian Bogor. Bogor.

Arif, A.B., S. Sujiprihati, M. Syukur. 2011. Pewarisan sifat beberapa karakter kualitatif pada tiga kelompok cabai. Bul. Plasma Nutfah 17(2): 73-79.

Bosland, P. W., E. J. Votava. 1999. Peppers : Vegetable and Spice Capsicums. CABI Pub. New York.

Burns, G. W. 1976. The Science of genetics : An Introduction to Heredity 3rd edition. Macmillan Publ. Co. New York.

Cayanti, R.E.O. 2006. Pengaruh media terhadap kualitas cabai hias (Capsicum sp.) dalam Pot. Skripsi. Program Studi Hortikultura, Institut Pertanian Bogor. Bogor.

Crowder, L.V. 2006. Genetika Tumbuhan. L. Kusdiarti, penerjemah. Gadjah Mada University Press, Yogyakarta. 
Djarwaningsih, T. 2005. Capsicum Spp. (cabai ): asal, penyebaran dan nilai ekonomi. Biodiversitas 6(4):292-296.

Deviona, R. Yunianti, M. Syukur, M.R.A. Istiqlal. 2011. Analisis korelasi dan sidik lintas karakter fenotipik 15 genotipe cabai (Capsicum annuum L.) koleksi IPB. Prosiding Seminar Nasional Perhorti.

Falconer, D.S. 1981. Introduction to Quantitative Genetics. Longman, London (UK) and New York (US).

Fehr, W. R. 1987. Principles of Cultivar Development. Vol 1. Macmillan, New York (US) and London (UK).

Ganefianti, D.W., Yulian, A.N. Suprapti. 2006. Korelasi dan sidik lintas antara pertumbuhan, komponen hasil dan hasil dengan gugur buah pada tanaman cabai. J. Akta Agrosia 9(1):1-6.

Hessayon, D.G. 1993. The House Plant Expert. 5th. Transworld Pub Ltd. Auckland.

Hilmayanti, I., W. Dewi, Murdaningsih., M. Rahardja, N. Rostini, R. Setiamihardja. 2006. Pewarisan karakter umur berbunga dan ukuran buah cabai merah (Capsicum annuum L.). Zuriat 17:86-93.

[IPGRI] International Plant Genetic Resources Institute. 1995. Descriptors for Capsicum (Capsicum spp.). International Plant Genetic Resources Institute, Roma, ITA.

Lestari, A.D., W. Dewi, W.A. Qosim, M. Rahardja, N. Rostini, R. Setiamihardja. 2006. Variabilitas genetik dan heritabilitas karakter komponen hasil dan hasil lima belas genotip cabai merah. Zuriat 17(1): 94 -102 .

Marame, F., L. Desalegne, Hajrit-Singh, C. Fininsa, R. Sigvald. 2008. Genetic components and heritability of yield and yield related traits in hot pepper. Res. J. Agric. \& Biol. Sci. 4(6): 803-809.

Mustafa M., M. Syukur, S.H. Sutjahjo, Sobir. 2016. Estimation of genetic parameters, correlation, and genetic relationship of tomatoes genotype in lowland. Agrotech Journal ATJ 1(1): $19-25$.

Naktuinbouw. 2010. Calibration Books Capsicum annuum L, Sweet Pepper, Hot Pepper, Paprika, Chili. Version 1. Naktuinbouw, Variety Testing Department. The Ederlands.
Qosim, W.A., M. Rachmadi, J.S. Hamdani, I. Nuri. 2013. Penampilan fenotipik, variabilitas, dan heritabilitas 32 genotipe cabai merah berdaya hasil tinggi. J. Agron. Indonesia 41(2):140-146.

Setiadi. 2002. Bertanam Cabai. Penebar Swadaya. Jakarta.

Sidiq, A.R.F. 2016. Pendugaan Parameter Genetik dan Seleksi Karakter Kuantitatif Cabai Rawit (Capsicum annum L.) Populasi F3. Skripsi. Program Studi Hortikultura, Institut Pertanian Bogor. Bogor.

Sobir, M. Syukur. 2015. Genetika Tanaman. IPB Press, Bogor.

Sreelathakumary, I., L. Rajamony. 2004. Variability, heritability and genetic advance in chilli (Capsicum annuum L.). J. of Tro. Agri. 42 (2): 35 - 37.

Sujitno, E., M. Dianawati. 2015. Produksi panen berbagai varietas unggul baru cabai rawit (Capsicum frutescens) di lahan kering Kabupaten Garut, Jawa Barat. Pros. Sem. Nas. Masy. Biodiv. Indon. 1(4): 874-877.

Syukur, M., S. Sujiprihati, R. Yunianti. 2012. Teknik Pemuliaan Tanaman. Penebar Swadaya, Bogor.

Syukur, M., S. Sujiprihati, R. Yunianti, D.A. Kusumah. 2011b. Pendugaan ragam genetik dan heritabilitas karakter komponen hasil beberapa genotipe cabai. J. Agrivigor 10(2):148-156.

Syukur, M., S. Sujiprihati, R. Yunianti, K. Nida. 2011 a. Pendugaan komponen ragam, heritabilitas dan korelasi untuk menentukan kriteria seleksi cabai (Capsicum annum L.) Populasi F5. J. Hort. Indonesia 1(2):74-80.

Syukur, M., R. Yunianti, Rustam, Widodo. 2013. Pemanfaatan sumber daya genetik lokal dalam perakitan varietas unggul cabai (Capsicum annuum) tahan terhadap penyakit antraknosa yang disebabkan oleh Colletotrichum sp. JIPI. 18 (2): 67-72.

Undang. 2014. Identifikasi dua spesies cabai rawit dan pewarisan karakter penting pada cabai rawit spesies Capsicum annuum L. Tesis. Sekolah Pascasarjana. Institut Pertanian Bogor. Bogor.

Yunianti, R., S. Sastrasumarjo, S. Sujiprihati, M. Surahman, S. Hidayat. 2010. Kriteria seleksi untuk perakitan varietas cabai tahan Phytophtora capsici Leonian. J. Agron. Indonesia 38(2):122-129. 